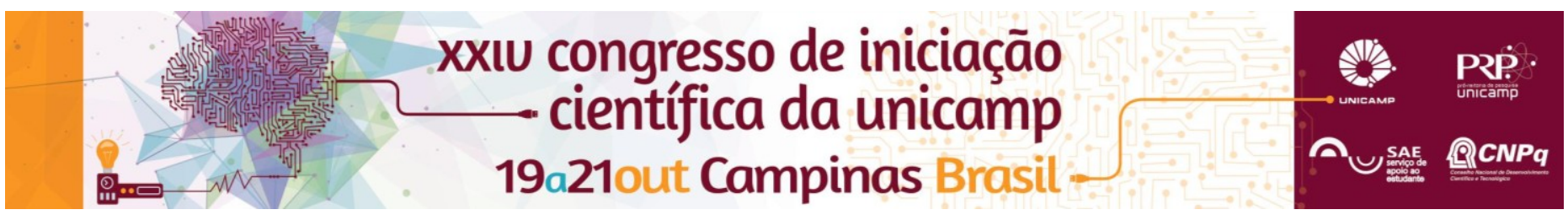

\title{
Moradores de Rua: estratégias e possibilidades de ação após o cárcere
}

\author{
Pedro Silva Vilas Bôas* (Bolsista PIBIC/CNPq), Prof. Dr. Michel Nicolau Netto.
}

\section{Resumo}

A presente pesquisa teve como escopo analisar as estratégias de ação de ex-presidiários que compõem parcela significativa dos moradores de rua da cidade de Campinas, após uma particular intervenção estatal, por meio da extensão repressiva do Estado, qual seja o Direito Penal. Para tanto, tal pesquisa também investigou quais concepções de Políticas Criminais são aplicadas em questões tradicionalmente tratadas no âmbito criminal do Ordenamento Jurídico Brasileiro.

\section{Palavras-chave \\ Política Criminal, Ex-presidiários, Moradores de Rua.}

\section{Introdução}

O veículo mais indicado para análise do antagonismo entre o mundo abstrato das normas e as relações concretas é a ponte que os conecta, que se traduz na Política Criminal aplicada como meio de combate à criminalidade, instrumentalizada na forma preventiva ou repressiva. A ideia de penitenciária não reside apenas na instituição, mas reveste-se na forma de um combinado de técnicas específicas, saberes e aparelhos repressivos, bem como métodos disciplinadores de exercício do poder. Ao considerar uma sociedade estratificada com grupos ocupando diferentes posições na estrutura social, mesmo o fracasso do presídio teria sua funcionalidade ao criar a figura do delinquente e da necessidade de isolá-lo, formalmente, através do cárcere ou, informalmente, através do processo de marginalização após o cárcere, que afeta uma porcentagem considerável dos moradores de rua na cidade de Campinas, a saber, de acordo com dados da Secretária de Cidadania da Prefeitura de Campinas, de julho de 2014, 33,8\% dos 642 moradores de rua cadastrados são ex-presidiários ${ }^{1}$.

Destarte, a presente pesquisa partiu da hipótese do Direito Penal como produtor de uma realidade social específica, ao construir representações denominadas criminosas que, ao instituir formalmente o tipo penal, reserva ao sistema penitenciário brasileiro papel de reprodutor da realidade social $^{3}$, ao atuar objetivamente sobre parcela significativa dos moradores de rua de Campinas. instituições consideradas preventivas, o agente social expresidiário que compõe parcela da categoria de morador de rua em Campinas, continua empreendendo ações estratégicas diante de micro relações de poder, ainda que setorizadas.

Ademais, acerca da metodologia, além do aprofundamento teórico sobre o tema, a pesquisa foi direcionada pela técnica "Observação Participante", comumente utilizada em pesquisas etnográficas, utilizando tais anotações como fonte para levantamento de dados qualitativos.

Usar esse espaço para referências, seguindo o estilo indicado - Padrão ACS ou ABNT ou Vancouver (letra Times 8). Ex:

1 Disponível em: <http://www.campinas.sp.gov.br/governo/cidadaniaassistencia-e-inclusao-social/relatorios.php>Acesso em: 29/10/2015 às 9:49h

FOUCAULT, Michel. Vigiar e Punir. Tradução de Raquel Ramalhete. 32a ed. Petrópolis, RJ: Vozes, 1987, p. 226.

BARATTA, Alessandro. Criminologia Crítica e Crítica do Direito Penal. Tradução de Juarez Cirino dos Santos. 6 ed. Rio de Janeiro, RJ: Revan, 2011.

\section{Resultados e Discussão}

Ao admitir que a lei se destine "a definir infrações, que o aparelho penal tenha como função reduzi-las e que a prisão seja o instrumento dessa repressão"2, a visão dessas formas jurídicas não escaparam à ideia de fracasso. Todavia, a concepção de fracasso do sistema penitenciário ultrapassa a própria ideia de fracasso constituindo, justamente esse fracasso, seu sucesso ao criar a figura do delinquente. Todavia, pode-se verificar que mesmo diante de instituições repressivas e 